\title{
Age at pubertal onset and educational outcomes"
}

\author{
Anna Dreber ${ }^{a}$, Emma von Essen $^{\mathrm{b}}$, and Eva Ranehill ${ }^{\mathrm{c}}$
}

First version: 2011-04-29

This version: 2011-09-13

\begin{abstract}
Education has important short and long run implications for individual outcomes. In this paper we explore the association between age at pubertal onset and educational outcomes in a sample of Swedish girls. Previous research suggests that girls that mature earlier perform worse in school compared to girls that mature later. To test if this is also true among Swedish girls, we investigate the association between pubertal development and grades, educational aspirations and educational choice. We also investigate whether changes in risk attitudes, time preferences and priorities concerning school versus friends mediate this potential correlation. We confirm that earlier maturing girls have lower grades and lower educational aspirations, but find that they make educational choices similar to those of later maturing girls. Furthermore, we do not find that these differences in grades and aspirations are mediated by risk attitudes, time preferences or priorities.
\end{abstract}

Keywords: educational outcomes, puberty, pubertal timing, grades

JEL codes: I0, J1, J16

\footnotetext{
* We are very grateful to the participating schools for making this study possible. We would also like to thank Johan Almenberg, Simon Gächter, Magnus Johannesson, Astri Muren and David G. Rand for valuable feedback on an earlier draft. Financial support from the Jan Wallander and Tom Hedelius Foundation and the Carl Silfvén Foundation (E.R) is gratefully acknowledged, as well as financial support from the Swedish Council for Working Life and Social Research (FAS).

${ }^{a}$ Department of Economics, Stockholm School of Economics. Email: anna.dreber@hhs.se

${ }^{\mathrm{b}}$ Department of Economics, Stockholm University. Email: emma.vonessen@ne.su.se

${ }^{\mathrm{c}}$ Department of Economics, University of Zurich. Email: eva.ranehill@econ.uzh.se
} 


\section{Introduction}

Educational outcomes have important impacts on the individual, in the short run as well as in the long run. For example, secondary school outcomes correlate with important subsequent outcomes in life through their effect on college enrollment, childbearing, income, health and mortality (Angrist and Krueger 1991, Pallas 2000). It is therefore important to study the determinants of the individual variation in educational outcomes.

In economics, the literature studying educational outcomes has mainly focused on family characteristics, such as parental education, income and occupation, as well as individual characteristics, such as gender and birth month (Mehgir and Palme 2004, Fredriksson and Öckert 2009, Björklund et al. 2010). Meanwhile, a number of studies in sociology and developmental psychology have pointed to the importance of pubertal development for educational outcomes. Puberty typically occurs around the ages 10-14 among girls, and is a period of major physical, hormonal, psychological and behavioral change. Some studies find that, on average, girls that mature earlier have lower grades (Simmons and Blyth 1987, Dubas et al. 1991, Cavanagh et al. 2007), lower academic goals (Dubas et al. 1991, Graber et al. 1997), and a higher probability of dropping out of school early (Cavanagh et al. 2007). However, the relationship between early puberty and educational outcomes among girls is not always found (Stattin and Magnusson 1990, Dubas et al. 1991, Graber et al. 1997, Koivusiltay and Rimpelä 2004). ${ }^{1}$ For boys, the relationship appears to be the opposite; earlier maturing boys typically perform better than later maturing boys. In this paper we study how pubertal development in girls is associated with educational outcomes among a sample of 344 adolescents in Sweden. ${ }^{2}$

Pubertal development could affect educational outcomes through various channels. A potential channel is through changes in risk attitudes and time preferences. One of the most salient characteristics of adolescence is an increase in behaviors with inherently risky and impulsive elements, such as drinking, smoking, and engaging in unprotected sex (Arnett

\footnotetext{
${ }^{1}$ Nevertheless, even in studies where there is no correlation between puberty and grades, such as in a previous Swedish study by Stattin and Magnusson (1990), early maturing girls experience school as more negative and play truant to a larger extent than later girls. Previous literature also shows that other incidences of negative consequences in relation to puberty among girls are the largest among those that mature early, when it comes to for example anxiety, depression, eating disorders, and substance abuse (see Mendle et al. 2007 for review). Early maturing girls are physically different from their same age peers and this may also lead to a negative selfappraisal.

${ }_{2}^{2}$ Adolescence is often referred to as the psychosocial transition between childhood and adulthood, and puberty, in a strict sense, refers to the physical sexual maturation. Adolescence overlaps somewhat with puberty, where the former is often roughly considered to be the period between 13 and 19 years of age.
} 
1999, Boyer 2006, Steinberg 2010). These behaviors have previously also been linked to low academic achievement among adolescents. ${ }^{3}$ Meanwhile, the onset of pubertal development occurs through hormone signals from the brain to the reproductive system, which thereafter produces hormones that affect the brain and other organs (Ellison 2001). There is some, albeit mixed, evidence of correlations between hormones, risk and time preferences (e.g. Takahashi et al. 2007, Apicella et al. 2008, Sapienza et al. 2009, Zethraeus et al. 2009). It is thus possible that these hormonal changes during puberty affect risk and time preferences.

A second channel through which pubertal development could affect educational outcomes is through changing priorities regarding school work vs. friends and romantic interests. Changes in priorities could be influenced by changes in preferences for these activities, or by differential treatment in the social environment, where relatively early maturing girls stand out and are given different attention by e.g. boys and parents compared to later maturing girls. Support for this channel is given by studies showing that girls who mature earlier are more likely to select into, and to be selected into, peer groups with older boys and girls that are characterized by riskier behavior and lower academic achievement (Stattin and Magnusson 1990, Haynie 2003). ${ }^{4}$

In our study, 344 girls are sampled in the $9^{\text {th }}$ grade when they are $15-16$ years old. This is the last year of compulsory education in Sweden and the year when students make their choice of secondary education. The educational outcomes we measure are grades, educational aspirations and educational choice, where the latter is indicated by the choice of vocational or academic track in secondary education. We further use three measures of self-reported pubertal development. Pubertal timing, the age when menarche occurs for girls, is our first measure of pubertal development. ${ }^{5}$ Our second measure is a compound variable of relative pubertal development in five areas of physical change, where the participants rate their development in relation to other girls of the same age. Our third measure focuses on only one of these areas, namely relative breast development.

We find that girls that mature earlier, measured through pubertal timing, have lower grades as well as lower educational aspirations. Moreover, girls that develop breasts relatively early to their peers have significantly lower grades and are less likely to choose the academic track as

\footnotetext{
${ }^{3}$ For a review of this literature see http://aspe.hhs.gov/hsp/riskybehav01/index.htm, accessed April 15, 2011.

${ }^{4}$ If early maturing girls have more peers with riskier behavior, and value friends more than school, this further supports the importance of looking at risk preferences since the peer network might reflect underlying similarities in preferences rather than peer effects.

${ }^{5}$ For a discussion regarding the onset of menarche as a measure of pubertal development see Dorn et al. (2010).
} 
their educational choice in high school. The compound measure of relative pubertal development, however, is consistently insignificant.

We also attempt to understand whether the two different channels that we propose can mediate the relationship between pubertal development and educational outcomes. We thus measure attitudes for risk as well as time preferences (i.e. patience). To our knowledge, this has previously not been explored in the literature linking pubertal development to educational outcomes. We further measure the subjective importance of school versus friends. In line with previous literature, we find that patience has positive implications for educational outcomes. In contrast, unlike in previous literature we find that a high risk taking propensity has negative implications for educational outcomes. However, we do not find any evidence that risk attitudes, time preferences or changes in priorities regarding school versus friends mediate the relation between puberty and educational outcome, and there is no correlation between the potential mediating factors and pubertal development.

Moreover, age at menarche is partly heritable (Ellison 2001), and the impact of early pubertal development on educational outcomes may thus be overestimated through the impact of socio-economic background on educational outcomes. However, in our sample there is no clear evidence of a correlation between pubertal development and socio-economic background, and the effect of pubertal development on educational outcomes is generally robust to controlling for the parents' socio-economic background. ${ }^{6}$ Here we thus include a set of demographic variables as additional control variables: age, parental education and the number of siblings. We find that our results are robust to the inclusion of these controls.

There relevant literature in economics is relatively scarce. An exception is Pekkarinen (2005), who presents suggestive evidence of the impact of puberty on educational choice. Investigating the effect of a change in the tracking age to secondary education from 11-12 to 15-16 it is found that this favors girls compared to boys. The author argues that girls at the age of 15 or 16 have reached the end of puberty, whereas boys are in the middle of it, and that being in the middle of puberty has adverse effects on educational aspirations.

In sum, our findings suggest that girls that mature earlier have lower grades as well as lower educational aspirations, and girls that develop breasts relatively early to their peers have lower

\footnotetext{
${ }^{6}$ For example, Obeidallah (2000) and Windham et al. (2009) find that higher socio-economic status is correlated with lower age at menarche, Semiz et al. (2009) find no relationship, and Short and Rosenthal (2008) as well as Semiz et al. (2009) find that in-family stress such as disease, conflict or absent fathers is associated with lower age at menarche.
} 
GPA and are less likely to choose an academic track in high schools. Risk attitudes and time preferences influence educational outcomes, but do not appear to mediate the relationship between pubertal development and educational outcomes. An important caveat is that our study does not allow us to infer causality. Our results should be seen as a first step investigating the relationship between pubertal timing and educational choice from an economic perspective. Future studies should attempt to further investigate the mechanisms behind the correlation between pubertal timing and educational outcomes, preferably in a large longitudinal sample.

The outline for the paper is the following. In section 2, we present the survey design. Section 3 presents our results, and section 4 concludes with a discussion of our findings.

\section{Design of study}

\subsection{Survey description}

All relevant schools in the Swedish cities Stockholm and Malmö that had contact information on their webpage were contacted via email. ${ }^{7} 11$ schools agreed to participate in the study. Though we have selection at the school level that we cannot control for, all students present at the day of the survey participated. The study was conducted in April and May 2009 and 2010, just after the students had made their choices of specialization to secondary education. We thus have data on two different cohorts. The survey was introduced as part of the school curricula during a regular school class, headed by a teacher, the school nurse, and/or a study and career advisor depending on the preference of the school. ${ }^{8}$ The survey consisted of four parts.

The first part included hypothetical measures of risk attitudes and time preferences. Risk attitudes are measured by a question where the subjects are asked to self-report their general risk taking propensity on a scale from 1 to 10 , where 10 is "very risk taking" and 1 is "not risk taking at all". This measure has been used in e.g. Dohmen et al. (2011) where it was found to predict incentivized risk taking as well as risk taking in other domains. Time preferences, i.e. patience, were assessed through a set of questions where participants had to choose between

\footnotetext{
${ }^{7}$ The principal and the study and career advisor of all schools with grade 9 were contacted. Schools with a particular religious or pedagogical focus were not contacted. A comparison of the data collected in each city reveals that whereas GPA is somewhat higher in the Stockholm sample $(p=0.093)$ and the educational aspirations are somewhat lower $(\mathrm{p}=0.099)$. Further, the Stockholm sample is slightly less risk taking $(\mathrm{p}=0.012)$ and have 0.3 more siblings $(\mathrm{p}=0.087)$.

${ }^{8}$ Every school in Sweden has a career advisor in order to inform students about alternative future educational options.
} 
hypothetical money "now" or hypothetical money "later". The amount of money "later" was fixed whereas money "now" increased for each pair of alternatives. $23 \%$ of the participants provided inconsistent answers (i.e. switched between money now and money later multiple times). We therefore used the number of choices for money later, of 19 possible pairs of alternatives, as our variable for patience.

The second part inquired about school related variables. In this part we collected three outcome variables; grades, educational aspirations and the choice of secondary education. In Sweden, grades is specified every semester from the $8^{\text {th }}$ grade and onwards, consisting of the grade in each course weighted by size of the course (in number of hours). ${ }^{9}$ To some extent the grades obtained correlates with subsequent educational choices, as some popular specializations require a higher grades. It is not, however, the case that an academic specialization always requires a higher grades than a vocational educational choice. In order to measure educational aspiration, we asked the participants to state the highest type of diploma they wished to obtain. This variable consisted of four categories where higher numbers implied higher diplomas (1 implies diploma from compulsory school, 2 diploma from high school, 3 diploma from tertiary education, excluding university, and 4 diploma from university). We also included a variable for educational choice, indicating whether the student had chosen an academic specialization or a vocational specialization as secondary education. Sweden has 9 years of compulsory schooling, starting the year a child turns 7 . In the $9^{\text {th }}$ grade, the large majority of students choose a specialization for secondary education. ${ }^{10}$ At the time of the study there were 17 possible different specializations; 15 vocational and 2 academic. ${ }^{11}$ All specializations comply with the minimal standards for access to tertiary education. However, most higher education requires complementary studies unless students have attended one of the two academic specializations. The choice consists of up to three ranked pairs of schools and specializations. We focus on the first pair; the participant's favored choice, creating a binary choice variable.

In the second part we also included additional school related measurements such as the importance of friends in relation to school (the obtained grades), time spent studying and time spent with friends, as well as parents' educational aspirations for their daughter. The questions

\footnotetext{
9 The grading scale has four levels: "fail", "pass", "pass with distinction" and "excellent" (the authors' translation), where fail corresponds to 0 points, pass corresponds to 10 points, pass with distinction corresponds to 15 points and excellent corresponds to 20 points.

${ }^{10}$ There are only 9 students in our sample dropping out of school after the $9^{\text {th }}$ grade. Hence we cannot use drop out or not as an outcome variable.

${ }^{11}$ Within several of these specializations there are sub-specializations.
} 
pertaining to the importance of school and friends both assessed answers on a scale from 110. We divided the answer on importance of school with the answer on importance of friends to measure the relative value the participants' placed on school versus friends.

The third part of the survey investigated puberty and health related outcomes. In the literature puberty is measured in a number of ways, ranging from invasive and non-invasive clinical examinations, to self-reported measurements. In the context of the present study only the latter approach was considered appropriate and feasible. ${ }^{12}$ We have three measures of pubertal development for girls; one measure of pubertal timing and two measures of relative pubertal development. In order to measure pubertal timing we ask the girls to state the year and the semester when they received their first menstruation. Pubertal timing is simply the age of menarche. We also include a set of questions on relative pubertal development. These are based on the most widely used self-report measurement of relative pubertal development, the Pubertal Development Scale, PDS (Petersen et al. 1988). The PDS consists of a set of questions, asking the respondent to rate their status of physical pubertal maturation based on five criteria; breast development, growth spurt, body hair, skin changes, menstruation. Given its structure, the PDS is mainly suitable for longitudinal studies. Since we measure pubertal development retrospectively, when most girls are at a similar and later stage of pubertal development, we therefore changed the possible answers of the PDS scale so that they would be more suitable for this. Instead of asking the respondents to rate their pubertal status, we followed the approach used in another self-report measure developed by Kaiser and Gruzelier (1999) asking the respondent to rate the timing of pubertal onset relative to other girls of the same age. We also added a question about general development, also inspired by Kaiser and Gruzelier (1999). Participants were asked to pin down the ratings on a 5 degree scale, where 1 corresponded to "much earlier than other girls", 2 to "somewhat earlier than other girls", 3 to "about the same as other girls", 4 to "somewhat later than other girls", and 5 to "much later than other girls". ${ }^{13}$ From these questions we created two variables of relative pubertal development. First we use five of these questions (all but the question on general development) to create a compound variable that we refer to as relative pubertal

\footnotetext{
12 In our sample most female participants are at a later stage of their pubertal development. Clinical measurements would probably have required repeated measurements or a measurement at a point earlier in time to provide the required variation. Self-reported measurements may also more accurately reflect the individual perception of relative pubertal development, which is partly what we are interested in investigating,

13 The exact question read "For each question, category a-f below, please indicate how you think your development in this area corresponds to other girls your age by ticking the alternative that you think describes you the best".
} 
development. ${ }^{14}$ Second, since breast growth is arguably the most parable change to others we used this question also as a separate variable. ${ }^{15}$

The last part of the survey included demographic questions such as year and month of birth, number and sex of siblings and parental education. ${ }^{16}$ Parental education was measured similarly to the educational aspiration level, though we differed between theoretic and vocational secondary education implying that this variable has 5 categories where, as before, higher numbers pertain to higher diplomas. Appendix Table A1 provides a list of all variables included in the analysis. ${ }^{17}$

Our dataset allows us to identify correlations only, and though participating schools come from areas with different socio-economic background, generalizations should be made with great caution. Furthermore, a longitudinal approach also including clinical measurements of pubertal development would of course have increased the quality of our data. This study should therefore be seen as a first attempt to study the influence of puberty and its mediating mechanisms on educational outcomes.

\subsection{Hypotheses and tests}

In accordance with most previous literature we hypothesized that early maturing girls would obtain lower grades and have lower educational aspirations than their later maturing peers. In addition, previous literature finds that early girls are more exposed to older peers and deviant behavior. They have also been found to experience school more negatively. We thus also hypothesized that early girls would exhibit lower motivation for studies and therefore have lower educational aspirations and be more likely to choose vocational tracks than their later maturing peers. Moreover, the measures of relative pubertal development further allow us to explore whether girls' assessments of their relative development matter as much as pubertal timing, where the latter is a measure of absolute timing. If this is the case, it could suggest an important role of feedback from the environment.

\footnotetext{
${ }^{14}$ The compound variable is highly correlated with self-reported general development (coefficient 0.698 and $\mathrm{p}<0.001)$.

${ }^{15}$ This part of the survey also included questions on height, weight, exercise, life satisfaction, "locus of control", the importance of having a partner and the importance of being good looking. We did not however use these variables in this paper since our sample is too small to use all variables in the analysis. We nevertheless chose to include these in the questionnaire for the purpose of future research studies.

16 This part also included questions about parental occupation, the respondent's origin and religiosity. The question about parental occupation was an open question and unfortunately the quality of the data was too bad to be included in the analysis. Origin, sex of siblings and religiosity were also not used in the analysis.

${ }^{17} \mathrm{We}$ also collected the corresponding data for boys in the surveyed classes. However, among boys partial attrition was much larger. In this paper we thus only focus on girls.
} 
We further had some expectations regarding mediating variables. We hypothesized that early maturing girls would be more risk taking and impatient, as well as more prone to rate the importance of school versus friends lower than their later peers. In turn, we hypothesized that risk taking and impatience would be negatively correlated with educational outcomes whereas the correlation between the importance of school versus friends would be positively correlated.

\section{Results}

\subsection{Descriptive statistics}

A total of 344 girls participated in the survey. Table 1 below presents descriptive statistics and attrition for the variables used in the analysis. At the time of the study the participating girls are on average 15.9 years old, and reached menarche at the average age of 12.8. The compound variable of relative pubertal development shows that girls on average find their pubertal development as well as their breast development to be about the same as other girls. The median girl has a grade point average of 236 on a scale ranging up to 320 . In terms of educational aspirations, $68 \%$ of the girls in our sample aspire to get a university education whereas $73 \%$ of the girls chose an academic specialization when it comes to secondary education. $^{18}$

Table 1. Descriptive statistics, 344 respondents

\begin{tabular}{lccccccc}
\hline \hline Variable & mean & p50 & N & sd & se(mean) & min & Max \\
\hline Timing & 12.75 & 12.71 & 324 & 1.07 & .06 & 10.67 & 16 \\
Puberty 5 & 2.86 & 3 & 338 & .58 & .03 & 1 & 5 \\
Breast & 2.87 & 3 & 338 & .88 & .05 & 1 & 5 \\
Continue studying & .97 & 1 & 343 & .16 & .01 & 1 & 1 \\
Grades & 236 & 240 & 301 & 46.51 & 2.68 & 95 & 320 \\
Aspirations & 3.49 & 4 & 297 & .83 & .05 & 1 & 4 \\
Educational choice & .73 & 1 & 334 & .44 & .02 & 0 & 1 \\
Risk & 5.89 & 6 & 336 & 1.70 & .09 & 1 & 10 \\
Patience & 10.01 & 9 & 344 & 5.86 & .32 & 0 & 19 \\
School versus friends & 1.06 & 1 & 341 & 0.53 & 0.03 & 0.22 & 7 \\
Age & 15.87 & 15.92 & 337 & .34 & .02 & 14.33 & 16.83
\end{tabular}

\footnotetext{
${ }^{18}$ Only $2.6 \%$ of our sample did not indicate a choice of secondary education.
} 


\section{Education father}

Education mother

\# siblings
4.08

4.09

1.63
1.51

1.32

1.05
.09

.08

.06
6

6

7 participants did either omit the year or the month they were born and 2 girls did not answer whether they had reached menarche. An additional 3 girls answered that they had not yet had their menses, thus these girls were excluded in the main analysis. In the remaining sample, 8 girls omitted information about which school year they reached menarche. For the 14 girls that did not state which term they got their first menstruation, we assigned the timing to be the average of that school year (between fall and spring semester).

\subsection{Regression analysis}

We look at how pubertal timing, relative pubertal development and relative breast development correlate with grades, educational aspirations and educational choice in separate regressions. ${ }^{19}$ Our main analysis is a regression analysis, based on OLS regressions. ${ }^{20} \mathrm{We}$ conduct three types of regressions for each pubertal and educational variable. First we study the educational variables only including each of the three different pubertal development variables separately. Second we add the three variables we expect to be mediating the effect of puberty on educational outcomes. Third we include a set of demographic control variables that could be important in understanding educational outcomes in each separate regression. This provides us with nine separate regressions per educational choice variable.

\subsubsection{Grades}

Table 2 shows that pubertal timing appears to be of some importance for grades. When we only use pubertal timing as a regressor, we find that it is significantly positively correlated with grades $(\mathrm{p}=0.030)$. Everything else equal, reaching menarche one year later corresponds to an increase in grades of about 7 points in our sample, i.e. an improvement of about 0.15 standard deviations. ${ }^{21}$ When we add the potential mediating variables, we find that effect of pubertal timing remains about the same in size and significance $(\mathrm{p}=0.027)$. The results from a correlation analysis also confirm that the puberty variables are uncorrelated with the mediating variables risk attitudes, time preferences and priorities regarding the importance of

\footnotetext{
${ }^{19}$ For each pubertal development variable, all regressions are run with a sample not including partial attrition so that we can compare significance and effect sizes with and without controls. We do not analyze the self-reported general development variable since we create a compound variable that is supposed to capture the same thing but has more variation with the help of the five questions on specific areas of relative general development.

${ }^{20}$ To control that our results are not dependent on specification, functional form, or regression method we further conducted a logit regression for the binary outcome variable of educational choice, and a tobit regressions for the truncated outcome variable educational aspirations, see Appendix Tables A2 and A3. We have also tested including a control for weight. This does not alter our results qualitatively.

${ }^{21}$ When running regressions without control variables pubertal timing has a larger effect size, 6.94 GPA.
} 
school to friends. Further, when adding the demographic control variables age, parental education and number of siblings to the regression, the effect of pubertal timing decreases to about 6 points and becomes marginally significant $(\mathrm{p}=0.057)$.

We do not find any evidence of relative pubertal development being significantly related to grades. When including relative breast development by itself, however, it is positively and significantly related to grades $(\mathrm{p}=0.020)$. The result is similar when we include the potential mediating factors $(\mathrm{p}=0.036)$, and as for pubertal timing, the effect is lower and marginally significant when we add the controls $(\mathrm{p}=0.058)$. Since a higher value on breast development corresponds to later development, this result supports our hypothesis.

Time preferences appear to influence grades; patience correlates positively with grades. There is also some evidence of a negative relationship with risk taking. ${ }^{22}$ We find no evidence of a correlation between grades and priorities regarding how much the girls value school relative to friends. Among the socio-demographic variables, only the father's education is marginally significantly positively correlated with grades.

Table 2. Pubertal development and grades, OLS regression

\begin{tabular}{|c|c|c|c|c|c|c|c|c|c|}
\hline VARIABLES & (1) & (2) & (3) & (4) & (5) & (6) & (7) & (8) & (9) \\
\hline Timing & $\begin{array}{l}6.940 * * \\
(2.179)\end{array}$ & $\begin{array}{c}6.562 * * \\
(2.226)\end{array}$ & $\begin{array}{l}5.826 * \\
(1.916)\end{array}$ & & & & & & \\
\hline Puberty 5 & & & & $\begin{array}{c}3.411 \\
(0.618)\end{array}$ & $\begin{array}{c}2.383 \\
(0.464)\end{array}$ & $\begin{array}{c}1.447 \\
(0.277)\end{array}$ & & & \\
\hline Breast & & & & & & & $\begin{array}{c}8.331 * * \\
(2.338)\end{array}$ & $\begin{array}{c}7.271 * * \\
(2.108)\end{array}$ & $\begin{array}{l}6.654 * \\
(1.908)\end{array}$ \\
\hline Risk & & $\begin{array}{l}-3.282^{*} \\
(-1.875)\end{array}$ & $\begin{array}{l}-3.375^{*} \\
(-1.958)\end{array}$ & & $\begin{array}{l}-3.299 * \\
(-1.874)\end{array}$ & $\begin{array}{l}-3.337 * \\
(-1.930)\end{array}$ & & $\begin{array}{c}-2.773 \\
(-1.590)\end{array}$ & $\begin{array}{l}-2.864 * \\
(-1.658)\end{array}$ \\
\hline Patience & & $\begin{array}{c}2.126 * * * \\
(4.061)\end{array}$ & $\begin{array}{c}2.051 * * * \\
(4.032)\end{array}$ & & $\begin{array}{c}2.149 * * * \\
(4.162)\end{array}$ & $\begin{array}{c}2.063 * * * \\
(4.084)\end{array}$ & & $\begin{array}{c}2.125 * * * \\
(4.161)\end{array}$ & $\begin{array}{c}2.047 * * * \\
(4.086)\end{array}$ \\
\hline Priorities & & $\begin{array}{c}4.683 \\
(0.738)\end{array}$ & $\begin{array}{c}6.650 \\
(1.094)\end{array}$ & & $\begin{array}{c}3.767 \\
(0.600)\end{array}$ & $\begin{array}{c}5.988 \\
(1.015)\end{array}$ & & $\begin{array}{c}4.535 \\
(0.695)\end{array}$ & $\begin{array}{c}6.542 \\
(1.061)\end{array}$ \\
\hline Age & & & $\begin{array}{c}-1.527 \\
(-0.167)\end{array}$ & & & $\begin{array}{c}-0.363 \\
(-0.0414)\end{array}$ & & & $\begin{array}{c}0.919 \\
(0.108)\end{array}$ \\
\hline Educ father & & & $\begin{array}{l}4.786 * \\
(1.677)\end{array}$ & & & $\begin{array}{l}5.019 * \\
(1.780)\end{array}$ & & & $\begin{array}{l}4.866^{*} \\
(1.716)\end{array}$ \\
\hline Educ mother & & & $\begin{array}{c}1.270 \\
(0.431)\end{array}$ & & & $\begin{array}{c}1.978 \\
(0.677)\end{array}$ & & & $\begin{array}{c}1.814 \\
(0.623)\end{array}$ \\
\hline \# siblings & & & $\begin{array}{c}-3.914 \\
(-1.315)\end{array}$ & & & $\begin{array}{c}-3.961 \\
(-1.359)\end{array}$ & & & $\begin{array}{c}-3.925 \\
(-1.321)\end{array}$ \\
\hline Observations & 235 & 235 & 235 & 239 & 239 & 239 & 239 & 239 & 239 \\
\hline
\end{tabular}


$\begin{array}{llllllllll}\text { R-squared } & 0.025 & 0.132 & 0.167 & 0.002 & 0.107 & 0.150 & 0.026 & 0.126 & 0.166\end{array}$

Robust t-statistics in parentheses. $* * * \mathrm{p}<0.01, * * \mathrm{p}<0.05, * \mathrm{p}<0.1$

\subsubsection{Educational aspirations}

We next turn to the impact of the puberty variables on educational aspirations. The results in Table 3 indicate that pubertal timing is positively related to educational aspirations when not controlling for anything else $(p=0.002)$, when controlling for the potential mediators $(\mathrm{p}=0.002)$ and when including the socio-demographic variables $(\mathrm{p}=0.009){ }^{23}$ This indicates that girls that enter puberty later have higher educational aspirations. We find no significant relationship between educational aspirations and either relative pubertal development or relative breast development.

When it comes to risk attitudes and time preferences, we find that risk taking is significantly negatively related to educational aspirations, with risk taking individuals being less likely to aspire for higher diplomas. There is some evidence of a positive correlation between patience and aspirations, when using the relative pubertal development variables. The father's own education level is positive and marginally significant in all specifications. Priorities regarding how much girls value school relative to friends seem to have no impact on aspirations.

Table 3. Pubertal development and educational aspirations, OLS regression

\begin{tabular}{|c|c|c|c|c|c|c|c|c|c|}
\hline VARIABLES & (1) & (2) & (3) & (4) & (5) & (6) & (7) & (8) & (9) \\
\hline Timing & $\begin{array}{c}0.150 * * * \\
(3.153)\end{array}$ & $\begin{array}{c}0.146 * * * \\
(3.125)\end{array}$ & $\begin{array}{c}0.124 * * * \\
(2.630)\end{array}$ & & & & & & \\
\hline Puberty 5 & & & & $\begin{array}{c}-0.028 \\
(-0.373)\end{array}$ & $\begin{array}{c}-0.042 \\
(-0.573)\end{array}$ & $\begin{array}{c}-0.049 \\
(-0.712)\end{array}$ & & & \\
\hline Breast & & & & & & & $\begin{array}{c}-0.001 \\
(-0.0124)\end{array}$ & $\begin{array}{c}-0.028 \\
(-0.499)\end{array}$ & $\begin{array}{c}-0.033 \\
(-0.592)\end{array}$ \\
\hline Risk & & $\begin{array}{c}-0.076 * * \\
(-2.209)\end{array}$ & $\begin{array}{c}-0.080 * * \\
(-2.313)\end{array}$ & & $\begin{array}{c}-0.076 * * \\
(-2.164)\end{array}$ & $\begin{array}{c}-0.079 * * \\
(-2.260)\end{array}$ & & $\begin{array}{c}-0.078^{* *} \\
(-2.204)\end{array}$ & $\begin{array}{c}-0.082 * * \\
(-2.308)\end{array}$ \\
\hline Patience & & $\begin{array}{c}0.014 \\
(1.552)\end{array}$ & $\begin{array}{c}0.013 \\
(1.489)\end{array}$ & & $\begin{array}{c}0.018 * * \\
(1.993)\end{array}$ & $\begin{array}{c}0.017 * \\
(1.960)\end{array}$ & & $\begin{array}{c}0.018 * * \\
(1.972)\end{array}$ & $\begin{array}{c}0.017 * \\
(1.935)\end{array}$ \\
\hline Priorities & & $\begin{array}{c}-0.147 \\
(-1.206)\end{array}$ & $\begin{array}{c}-0.120 \\
(-1.117)\end{array}$ & & $\begin{array}{c}-0.167 \\
(-1.417)\end{array}$ & $\begin{array}{c}-0.138 \\
(-1.359)\end{array}$ & & $\begin{array}{c}-0.169 \\
(-1.430)\end{array}$ & $\begin{array}{c}-0.140 \\
(-1.380)\end{array}$ \\
\hline Age & & & $\begin{array}{c}0.112 \\
(0.795)\end{array}$ & & & $\begin{array}{c}0.180 \\
(1.301)\end{array}$ & & & $\begin{array}{c}0.180 \\
(1.304)\end{array}$ \\
\hline Educ father & & & $\begin{array}{l}0.081 * \\
(1.709)\end{array}$ & & & $\begin{array}{l}0.082 * \\
(1.728)\end{array}$ & & & $\begin{array}{l}0.081 * \\
(1.732)\end{array}$ \\
\hline Educ mother & & & $\begin{array}{c}0.074 \\
(1.355)\end{array}$ & & & $\begin{array}{c}0.084 \\
(1.503)\end{array}$ & & & $\begin{array}{c}0.085 \\
(1.506)\end{array}$ \\
\hline \# siblings & & & $\begin{array}{c}-0.044 \\
(-0.802)\end{array}$ & & & $\begin{array}{c}-0.036 \\
(-0.663)\end{array}$ & & & $\begin{array}{c}-0.036 \\
(-0.675)\end{array}$ \\
\hline
\end{tabular}

\footnotetext{
${ }^{23}$ Running the same set of regressions while controlling for grades diminishes the effect of pubertal timing on educational aspirations to about half (see Appendix Table A4). Further, the coefficient is only significant at the $10 \%$ level in the first two specifications, and not at all in the third.
} 


\begin{tabular}{lccccccccc} 
Observations & 224 & 224 & 224 & 230 & 230 & 230 & 230 & 230 & 230 \\
R-squared & 0.042 & 0.080 & 0.137 & 0.000 & 0.047 & 0.116 & 0.000 & 0.047 & 0.117 \\
\hline
\end{tabular}

Robust t-statistics in parentheses. $* * * \mathrm{p}<0.01, * * \mathrm{p}<0.05, * \mathrm{p}<0.1$

\subsubsection{Educational choices}

Analyzing the impact of puberty on the choice of specialization, we find no relationship between educational choice and either pubertal timing or the compound relative pubertal development variable. ${ }^{24}$ Relative breast development, however, is positively and significantly or marginally significantly related to educational choice ( $\mathrm{p}=0.034, \mathrm{p}=0.044$, or $\mathrm{p}=0.076$ ). Even if the significance level changes, the coefficient remains rather stable across regressions. This indicates that girls that develop breasts relatively late are more likely to choose an academic track in high school. We also find that patience is positively significantly correlated with choosing the academic track.

Table 4. Pubertal development and educational choice, OLS regression

\begin{tabular}{|c|c|c|c|c|c|c|c|c|c|}
\hline VARIABLES & (1) & (2) & (3) & (4) & (5) & (6) & (7) & (8) & (9) \\
\hline Timing & $\begin{array}{c}0.019 \\
(0.718)\end{array}$ & $\begin{array}{c}0.017 \\
(0.687)\end{array}$ & $\begin{array}{c}0.015 \\
(0.564)\end{array}$ & & & & & & \\
\hline Puberty 5 & & & & $\begin{array}{c}0.044 \\
(0.969)\end{array}$ & $\begin{array}{c}0.038 \\
(0.849)\end{array}$ & $\begin{array}{c}0.029 \\
(0.620)\end{array}$ & & & \\
\hline Breast & & & & & & & $\begin{array}{c}0.060 * * \\
(2.128)\end{array}$ & $\begin{array}{c}0.057 * * \\
(2.028)\end{array}$ & $\begin{array}{l}0.052 * \\
(1.785)\end{array}$ \\
\hline Risk & & $\begin{array}{c}0.003 \\
(0.173)\end{array}$ & $\begin{array}{c}0.004 \\
(0.216)\end{array}$ & & $\begin{array}{l}-0.002 \\
(-0.111)\end{array}$ & $\begin{array}{c}-0.001 \\
(-0.0612)\end{array}$ & & $\begin{array}{c}0.002 \\
(0.139)\end{array}$ & $\begin{array}{c}0.003 \\
(0.152)\end{array}$ \\
\hline Patience & & $\begin{array}{c}0.014 * * * \\
(3.074)\end{array}$ & $\begin{array}{c}0.014 * * * \\
(2.940)\end{array}$ & & $\begin{array}{c}0.014 * * * \\
(2.999)\end{array}$ & $\begin{array}{c}0.013 * * * \\
(2.825)\end{array}$ & & $\begin{array}{c}0.014 * * * \\
(2.999)\end{array}$ & $\begin{array}{c}0.013 * * * \\
(2.837)\end{array}$ \\
\hline Priorities & & $\begin{array}{l}0.048 * \\
(1.728)\end{array}$ & $\begin{array}{c}0.057 * * \\
(2.044)\end{array}$ & & $\begin{array}{c}0.037 \\
(1.417)\end{array}$ & $\begin{array}{l}0.050^{*} \\
(1.833)\end{array}$ & & $\begin{array}{c}0.042 \\
(1.548)\end{array}$ & $\begin{array}{l}0.053^{*} \\
(1.915)\end{array}$ \\
\hline Age & & & $\begin{array}{c}-0.021 \\
(-0.288)\end{array}$ & & & $\begin{array}{l}-0.022 \\
(-0.319)\end{array}$ & & & $\begin{array}{c}-0.013 \\
(-0.184)\end{array}$ \\
\hline Educ father & & & $\begin{array}{c}0.003 \\
(0.115)\end{array}$ & & & $\begin{array}{c}0.005 \\
(0.220)\end{array}$ & & & $\begin{array}{c}0.005 \\
(0.205)\end{array}$ \\
\hline Educ mother & & & $\begin{array}{c}0.029 \\
(1.139)\end{array}$ & & & $\begin{array}{c}0.036 \\
(1.407)\end{array}$ & & & $\begin{array}{c}0.034 \\
(1.328)\end{array}$ \\
\hline \# siblings & & & $\begin{array}{c}0.004 \\
(0.154)\end{array}$ & & & $\begin{array}{c}0.004 \\
(0.151)\end{array}$ & & & $\begin{array}{c}0.004 \\
(0.143)\end{array}$ \\
\hline $\begin{array}{l}\text { Observations } \\
\text { R-squared }\end{array}$ & $\begin{array}{c}253 \\
0.002\end{array}$ & $\begin{array}{c}253 \\
0.050\end{array}$ & $\begin{array}{c}253 \\
0.059\end{array}$ & $\begin{array}{c}258 \\
0.004\end{array}$ & $\begin{array}{c}258 \\
0.047\end{array}$ & $\begin{array}{c}258 \\
0.062\end{array}$ & $\begin{array}{c}258 \\
0.016\end{array}$ & $\begin{array}{c}258 \\
0.059\end{array}$ & $\begin{array}{c}258 \\
0.072\end{array}$ \\
\hline
\end{tabular}

Robust t-statistics in parentheses. $* * * \mathrm{p}<0.01, * * \mathrm{p}<0.05, * \mathrm{p}<0.1$

\section{Discussion}

\footnotetext{
${ }^{24}$ Similarly to the previous case, running the same set of regressions controlling for GPA diminishes the effect of relative breast development to about half the size noted in table 4 (see Appendix Table A5). Further the coefficient is no longer significant.
} 
Given the short and long run impacts of educational outcomes for the individual, it is important to understand the determinants of e.g. grades, educational aspirations and educational choice. In this study we replicated the common finding that girls who mature early perform worse in school and have lower educational aspirations with a sample of 15-16 year old girls in Sweden. Our results also suggest that later maturing girls, when it comes to relative breast development, have higher grades and are more likely to choose the academic track in high school. Moreover, we explored possible mediating factors in order to explain this relationship. We hypothesized that changes in risk attitudes and time preferences, perhaps associated with hormonal changes during puberty, were one channel through which puberty could affect educational outcomes. We also hypothesized that changes in priorities, where earlier girls would put less emphasis on school relative to friends, would be another mediating factor. We found no evidence of any of these variables mediating the correlation between early pubertal development and educational outcomes. Risk attitudes and patience, but not priorities, correlate to some extent with educational outcomes, but are uncorrelated with pubertal development. However, this study should be seen as an exploratory attempt, and not as a conclusive study on the role of these mediating factors.

Puberty is typically related to an increase in behaviors that are associated with risk taking and impulsivity. However, when it comes to comparing different age groups in studies in economics and developmental psychology, most of the focus has been on adolescence rather than puberty. Some studies find that adolescents are more risk taking and less patient than other groups (e.g. Steinberg et al. 2008, Burnett et al. 2010), whereas other studies find a linear decrease in impulsive and risky behavior from childhood to adulthood (Green et al. 1994, Bettinger and Slonim 2007) and yet others do not find a difference across age groups (Harbaugh et al. 2002, van Leijenhorst et al. 2008, Sutter et al. 2010). However, puberty and adolescence only overlap partially, thus it would be of interest to focus on whether boys and girls at different stages of puberty, and not just adolescents, act differently than other groups. Moreover, it is not clear whether experimentally elicited preferences for risk and time correspond easily to the propensity to engage in the risky and impulsive behaviors that typically are associated with puberty (see e.g. Sutter et al. 2010). This might be one explanation for why we do not find risk attitudes and time preferences to be mediating the relationship between pubertal development and educational outcomes.

Another reason for why we do not find any mediating effects of risk attitudes and time preferences could be due to the fact that we measure these at a point in time where most girls 
have reached a more advanced pubertal status. Potentially, differences in these preferences are larger when pubertal discrepancies are more important. However, our results suggest that risk attitudes and time preferences correlate with educational outcomes. Patience correlates positively with educational outcomes and risk taking negatively. A handful of studies have previously explored the relationship between educational outcomes and experimentally elicited preferences for risk and time. Benjamin et al. (2006) find that risk taking is positively correlated with standardized test scores, whereas Sutter et al. (2010) find no correlation between risk preferences and grades. Patience has been found to correlate negatively with deviant behavior in school (Castillo et al. 2008) and positively with grades (Kirby et al. 2005, Benjamin et al. 2006, Sutter et al. 2010). However, studying patience, cognitive capacity and imaginative powers, Borghans and Goldsteyn (2004) find a slightly more complicated picture. In their study, individuals with high time discounting (impatience) have lower grades but stay longer in college since they also have lower ability to imagine the future. Even if we use hypothetical measures of time preferences compared to other studies in economics our results are similar. When it comes to risk attitudes, however, our results differ somewhat from what previous economic literature has found. This may be due to the different measurements used. Whereas we use a hypothetical question about general risk attitudes, Benjamin et al (2006) measure financial risk taking through a series of financial gambles where the riskier choice often maximizes the expected value.

Puberty could further affect decision making pertaining to education through both its hormonal effects on the brain, and through its effect on how one is treated by the social environment. The latter is partly what we aimed to capture by the relative pubertal development measures we used, and in particular what we had in mind when we looked at the relative breast development variable, since this is arguably the most parable physical change of sexual character for girls during this period. Support of this reasoning comes from a study where relatively early maturing girls are shown to be treated differently by their peers, for example by boys (Stattin and Magnusson 1990). This might cause early maturing girls to change their behavior. With reliable measures of pubertal development and complete information on peer groups this could be explored further. Another natural extension is also to study same-sex schools, in order to see whether the effects are similar in those schools compared to mixed schools.

Our study highlights the importance of including pubertal development measures in studies regarding educations outcomes. Nevertheless, a number of caveats should be kept in mind 
when interpreting the results. Though we have no selection into our study at the student level we have selection at the school level, and the sample included in this study is unlikely to be representative of the population in Sweden as a whole. Sampling schools at the end of the last semester of the compulsory school, when schools with less advantaged students work hard to get as many students to pass as possible, may have led to a selection towards the upper end of the spectra of socio-economic status. Further, sampling schools in two of the biggest cities in Sweden probably exacerbated this. This is also apparent when we look at the data. For example, our sample has higher grades than the national average, even if we compare with the average in big cities. One can only speculate whether the impact of puberty would have been greater or not had we had access to a different sample. However our estimates are not likely to be an overestimation of the true effects. For example, with respect to educational choice, where we find the weakest results, it is for example worth noting that all (50) of the students in one of the participating schools chose an academic specialization. Pubertal timing may have a larger impact on educational outcomes among students from less affluent areas. Further, we only investigated girls and only relied on self-reported answers related to pubertal timing and relative pubertal development. Future research should use larger longitudinal studies with more objective measures from e.g. hormonal measurements in order to explore the potential impact of gender differences regarding pubertal development and educational outcomes. 


\section{References}

Aksglaede, L., Sørensen, K., Petersen, J.H., Skakkebaek, N.E., Juul, A., 2009, "Recent Decline in Age at Breast Development: The Copenhagen Puberty Study." Pediatrics, 123:5, 932-9.

Angrist, J.D., Krueger, A.B., 1991, ’Does Compulsory School Attendance Affect Schooling and Earnings?" Quarterly Journal of Economics, 106:4, 979-1014.

Apicella, C.L., Dreber, A., Campbell, B.C., Gray, P.B., Hoffman, M., Little, A.C., "Testosterone and Financial Risk Preferences." Evolution and Human Behavior, 29:6, 384390.

Arnett, J., 1999, “Adolescent Storm and Stress, Reconsidered.” American Psychologist, 54, 317-26.

Benjamin, D.J., Brown, S.A., Shapiro, J.M., 2006, "Who is Behavioral? Cognitive Ability and Anomalous Preferences.” Mimeo. Harvard University.

Bettinger, E., Slonim, R., 2007, “Patience among Children.” Journal of Public Economics 91, 343-363.

Björklund, A., Lindahl, L., and Lindquist, M. J., 2011, "What More than Parental Income, Education and Occupation? An Exploration of what Swedish Siblings Get from their Parents." The B.E. Journal of Economic Analysis \& Policy, 10:1.

Blumenthal, H., Leen-Feldner, E.W., Trainor, C.D., Babson, K.A., Bunaciu, L., 2009, "Interactive Roles of Pubertal Timing and Peer Relations in Predicting Social Anxiety Symptoms among Youth.” Journal of Adolescent Health, 44, 401-403.

Borghans, L., Golsteyn, B., 2005, "Imagination, Time Discounting and Human Capital Investments." Mimeo.

Boyer, T., 2006, "The Development of Risk-Taking: A Multi-Perspective View." Developmental Review, 26:291-345.

Burnett, S., Bault, N., Coricelli, G., Blakemore, S.J., 2010, “Adolescents’ Heightened RiskSeeking in a Probabilistic Gambling Task.” Cognitive Development. 25:2,183-196.

Cavanagh, S., Riegle-Crumb, C., Crosnoe R., 2007, "Puberty and the Education of Girls." Social Psychology Quarterly, 70:2, 186-198.

Castillo, M., Ferraro, P., Jordan, J., Petrie, R., 2008, “The Today and Tomorrow of Kids.“ Working Paper, Georgia State University.

Dohmen, T., Falk, A., Huffman, D., Sunde, U., Schupp J., Wagner. G.G., 2011, Forthcoming. "Individual Risk Attitudes: Measurement, Determinants and Behavioral Consequences", Journal of the European Economic Association.

Dorn, L., Biro, F., 2011, "Puberty and its Measurement, a Decade in Review", Journal of research on Adolescence, 21 (1), 180-195.

Dubas, Semon J., Graber, J.A., Petersen, A.C., 1991, “The Effects of Pubertal Development on Achievement during Adolescence.” American Journal of Education, 99:4, 444-460.

Duke, P. M., Carlsmith, M., Jennings, D., Martin J. A., Dornbusch, S. M., Gross, R. T., Siegel-Gorelick, B., 1982, "Educational Correlates of Early and Late Sexual Maturation in Adolescence." The Journal of Pediatrics 100:4.

Ellison, P.T., 2001, On Fertile Ground. Harvard University Press, Cambridge, MA. 
Fredriksson, P., Öckert, B., 2005, "Is Early Learning Really More Productive? The Effect of School Starting Age on School and Labor Market Performance.” IZA DP No. 1659.

Graber, J. A., Lewinsohn, P. M., Seeley J. R., Brooks-Gunn, J., 1997, "Is Psychopathology Associated With the Timing of Pubertal Development?" Journal of the American Academy if Child and Adolescent Psychiatry 36:12,1768-76.

Green L., Fry, A.F., Myerson, J., 1994, " Discounting of Delayed Rewards: A Life-Span Comparison", Psychological Science, 5:1, 33-36.

Haynie, D.L., 2003, "Contexts of Risk? Explaining the Link between Girls Pubertal Development and Their Delinquency Involvement." Social Forces, 82, 355-397.

Harbaugh, W.T., Krause, K., Vesterlund, L., 2002, "Risk Attitudes of Children and Adults: Choices over Small and Large Probability Gains and Losses." Experimental Economics, 5:1, 53-84.

Kaiser, J., Gruzelier, J.H., 1999, "The Adolescence Scale (AS-ICSM): A Tool for the Retrospective Assessment of Puberty Milestones." Acta Paediatrics 88, 64-68.

Kaltiala- Heino, R., Kosunen, E., Rimpela, M., 2003, "Pubertal Timing, Sexual Behaviour and Self-Reported Depression in Middle Adolescence." Journal of Adolescence, 26, 531-545.

Kirby, C., Winston, G., Santiesteban, M., 2005, 'Impatience and Grades: Delay-Discount Rates Correlate Negatively with College GPA." Learning and Individual Differences, 15:3, 213-222.

Koivusiltay, L., Rimpelä. A., 2004, "Pubertal Timing and Educational Careers: A Longitudinal Study.” Annals of Human Biology, 31:4, 446-465.

Lanza, S.T., Collins, L.M., 2002, "Pubertal Timing and the Onset if Substance Use in Females During Early Adolescence.” Prevention Science 3:1, 69-82.

Van Leijenhorst, L., Westenberg. P.M., Crone, E.A., 2008, “A Developmental Study of Risky Decisions on the Cake Gambling Task: Age and Gender Analyses of Probability Estimation and Reward Evaluation.” Developmental Neuropsychology, 33:2, 179-196

Mendle, J., Turkheimer, E., Emery, R., 2007, “Detrimental Psychological Outcomes

Associated with Early Pubertal Timing in Adolescent Girls.” Developmental review, 27, 151171.

Obeidallah, D., Brennan, R.T., Brooks-Gunn, J., Earls, F., 2004, “Links Between Pubertal Timing and Neighbourhood Contents: Implications for Girls' Violent Behaviour." Journal of the American Academy of Child and Adolescent Psychiatry, 43, 1460-1468.

Pallas, A.M., 2000, “The Effects of Schooling on Individual Lives.” In Handbook of the Sociology of Education. Kluwer Academic/Plenum Publishers, New York.

Palme, M., Meghir, C., 2005, "Educational Reform, Ability and Parental Background." American Economic Review, 95:1, 414-424.

Pekkarinen, T., 2008, "Gender differences in educational attainment: Evidence on the role of tracking from a Finnish quasi-experiment.” Scandinavian Journal of Economics, 110:4, 807825.

Pergamit, M.R., Huang, L., Lane, J., 2001, “The Long Term Impact of Adolescent Risky Behaviors and Family Environment," Chicago, Ill.: National Opinion Research Center (NORC), University of Chicago. Available at: http://aspe.hhs.gov/hsp/riskybehav01. Accessed April 15, 2011. 
Petersen, A.C., Crockett, L., Richards, M., Boxer, A., 1988, “A Self-Report Measure of Pubertal Status: Reliability, Validity, and Initial Norms,' J. Youth Adolescence 17, 117-133.

Sapienza, P., Zingales, L., Maestripieri, D., 2009, “Gender Differences in Financial Risk Aversion and Career Choices are Affected by Testosterone." Proceedings of the National Academy of Sciences, 106:36, 15268-15273.

Simmons, R.G., Blyth, D.A., 1987, Moving into Adolescence. Hawthorne, N.Y.: Aldine De Gruyter.

Short, M.B., Rosenthal, S.L., 2008, "Psychosocial Development and Puberty." Annals of the New York Academy of Scienes, 1135, 36-42.

Stattin, H. and David M., 1990, Pubertal Maturation in Female Development. Hillsdale: Lawrence Erlbaum Associates.

Steinberg, L., 2010, "Commentary: A Behavioral Scientist Looks at the Science of Adolescent Brain Development.” Brain Cognition, 72:1, 160-164.

Sutter, M., Kocher, M.G., Rützler, D., Trautmann, S.T., 2010, "Impatience and Uncertainty: Experimental Decisions Predict Adolecents' Field Behavior." Discussion Papers in Economics 12114, University of Munich, Department of Economics.

Takahashi, T., Sakaguchi, K., Oki, M., Hasegawa, T., 2008, "Sex Hormonal Modulation of Hyperbolic Discount Factor in Men.” Journal of Neuroscience, Psychology, and Economics, $1: 1,7-16$.

Tanner J.M., 1989 Foetus into Man Ware. Castlemead Publications, 2.

Windham, G.C., Zhang, L., Longnecker, M.P., Klebanoff, M., 2008, "Maternal Smoking, Demographic and Lifestyle Factors in Relation to Daughter's Age at Menarche." Paediatric and Perinatal Epidemiology., 22:6, 551-61.

Zehr, J.L., Culbert, K.M., Sisk, C.L., Klump, K.L. 2007, “An Association of Early Puberty with Disordered Eating and Anxiety in a Population of Undergraduate Women and Men." Hormones and Behaviour, 52

Zethraeus, N., Kocoska-Maras, L., Ellingsen, T., von Schoultz, B., Lindén Hirschberg, A., Johannesson, M., 2009, "A Randomized Trial of the Effect of Estrogen and Testosterone on Economic Behavior." Proceedings of the National Academy of Sciences of the United States of America, 106, 6535-6538. 


\section{Appendix}

\section{Table A1. Variable description}

\begin{tabular}{|c|c|}
\hline Variable & Variable description \\
\hline Grades & Total grades obtained, weighted by the size of the course and in the range of $0-320$. \\
\hline Aspiration & $\begin{array}{l}\text { Highest diploma aimed four, } 1=\text { diploma compulsory school }(9 \text { years }), 2=\text { Diploma } \\
\text { secondary education }(12 \text { years }), 3=\text { diploma tertiary education excluding university, } \\
4=\text { diploma from university }\end{array}$ \\
\hline $\begin{array}{l}\text { Educational } \\
\text { choice }\end{array}$ & $\begin{array}{l}\text { Choice of academic or vocational track in secondary education, } 1=\text { academic track as } \\
\text { first choice }\end{array}$ \\
\hline $\begin{array}{l}\text { Pubertal } \\
\text { timing }\end{array}$ & Age ate menarche, measured in years \\
\hline Puberty 5 & $\begin{array}{l}\text { Average of five self-estimated ratings on pubertal progress in relation to same aged } \\
\text { peers. The scale ranged from } 1=\text { much earlier than other girls, to } 5=\text { much later than } \\
\text { other girls. The five estimations pertained to breast development, growth spurt, body } \\
\text { hair, skin problems and menstruation }\end{array}$ \\
\hline Breast & The self-estimated relative breast development used in puberty 5 on its own \\
\hline Risk & $\begin{array}{l}\text { Self reported general risk taking propensity, reported on a scale from } 1=\text { "not risk } \\
\text { taking at all" to } 10=\text { "very risk taking" }\end{array}$ \\
\hline Patience & $\begin{array}{l}\text { The number of patient choices in a hypothetical question involving a choice between } \\
\text { money now and later. The later amount was consistently } 200 \text { SEK, whereas the } \\
\text { mount to be obtained today ranged from } 20 \text { SEK to } 200 \text { SEK in brackets of } 10 \text { SEK }\end{array}$ \\
\hline Priorities & $\begin{array}{l}\text { The ration between a question asking participants to state the importance of getting } \\
\text { good grades from } 1-10 \text {, where } 10 \text { corresponded to very important, and a similar scale } \\
\text { asking about the importance of friends }\end{array}$ \\
\hline Age & Age in years \\
\hline Educ Father & $\begin{array}{l}\text { Father's education, } 1=\text { diploma from compulsory school, } 2=\text { diploma from vocational } \\
\text { secondary education, } 3=\text { diploma from academic secondary education, } 4=\text { diploma } \\
\text { from tertiary education excluding university, } 5=\text { diploma from university }\end{array}$ \\
\hline Educ Mother & $\begin{array}{l}\text { Mother's education, } 1=\text { diploma from compulsory school, } 2=\text { diploma from vocational } \\
\text { secondary education, } 3=\text { diploma from academic secondary education, } 4=\text { diploma } \\
\text { from tertiary education excluding university, } 5=\text { diploma from university }\end{array}$ \\
\hline \# siblings & Number of siblings. \\
\hline
\end{tabular}


Table A2. Educational aspirations, Tobit regression

\begin{tabular}{|c|c|c|c|c|c|c|c|c|c|}
\hline VARIABLES & (1) & (2) & (3) & (4) & (5) & (6) & (7) & (8) & (9) \\
\hline ageatmenarche & $\begin{array}{c}0.525 * * \\
*\end{array}$ & $\begin{array}{c}0.527 * * \\
*\end{array}$ & $\begin{array}{c}0.484 * * \\
*\end{array}$ & & & & & & \\
\hline & $(2.902)$ & $(3.018)$ & $(2.779)$ & & & & & & \\
\hline risk_general & & $-0.268 * *$ & $-0.262^{* *}$ & & $\begin{array}{c}- \\
0.226 * \\
*\end{array}$ & $0.221 * *$ & & $\begin{array}{c}- \\
0.230 * \\
*\end{array}$ & $\begin{array}{c}- \\
0.226 * \\
*\end{array}$ \\
\hline & & $(-2.395)$ & $(-2.379)$ & & $\begin{array}{c}(- \\
2.027)\end{array}$ & $(-2.027)$ & & $\begin{array}{c}(- \\
2.043)\end{array}$ & $\begin{array}{c}(- \\
2.059)\end{array}$ \\
\hline patientchoices & & $\begin{array}{c}0.037 \\
(1.166)\end{array}$ & $\begin{array}{c}0.039 \\
(1.204)\end{array}$ & & $\begin{array}{c}0.051 \\
(1.588)\end{array}$ & $\begin{array}{c}0.054^{*} \\
(1.683)\end{array}$ & & $\begin{array}{c}0.051 \\
(1.608)\end{array}$ & $\begin{array}{l}0.054^{*} \\
(1.691)\end{array}$ \\
\hline schooloverfriends & & $\begin{array}{l}-0.480 * \\
(-1.754)\end{array}$ & $\begin{array}{c}-0.414 \\
(-1.507)\end{array}$ & & $\begin{array}{c}-0.477^{*} \\
(- \\
1.720)\end{array}$ & $\begin{array}{c}-0.425 \\
(-1.532)\end{array}$ & & $\begin{array}{c}-0.483 * \\
(- \\
1.739)\end{array}$ & $\begin{array}{c}-0.427 \\
(- \\
1.543)\end{array}$ \\
\hline age & & & $\begin{array}{c}0.126 \\
(0.241)\end{array}$ & & & $\begin{array}{c}0.468 \\
(0.912)\end{array}$ & & & $\begin{array}{c}0.451 \\
(0.879)\end{array}$ \\
\hline education_father & & & $\begin{array}{c}0.098 \\
(0.753)\end{array}$ & & & $\begin{array}{c}0.094 \\
(0.726)\end{array}$ & & & $\begin{array}{c}0.098 \\
(0.761)\end{array}$ \\
\hline education_mother & & & $\begin{array}{c}0.123 \\
(0.845)\end{array}$ & & & $\begin{array}{c}0.143 \\
(1.007)\end{array}$ & & & $\begin{array}{c}0.145 \\
(1.017)\end{array}$ \\
\hline numbersiblings & & & $\begin{array}{c}-0.135 \\
(-0.818)\end{array}$ & & & $\begin{array}{c}-0.097 \\
(-0.589)\end{array}$ & & & $\begin{array}{c}-0.098 \\
(- \\
0.601)\end{array}$ \\
\hline averagepuberty 5 & & & & $\begin{array}{c}0.100 \\
(0.319 \\
)\end{array}$ & $\begin{array}{c}0.044 \\
(0.143)\end{array}$ & $\begin{array}{c}0.011 \\
(0.0366 \\
)\end{array}$ & & & \\
\hline relative_puberty_brea & & & & & & & 0.018 & -0.054 & -0.076 \\
\hline & & & & & & & $\begin{array}{c}(0.0881 \\
)\end{array}$ & $\begin{array}{c}(- \\
0.273)\end{array}$ & $\begin{array}{c}(- \\
0.389)\end{array}$ \\
\hline Observations & 214 & 214 & 214 & 216 & 216 & 216 & 216 & 216 & 216 \\
\hline
\end{tabular}

$* * * \mathrm{p}<0.01, * * \mathrm{p}<0.05, * \mathrm{p}<0.1$

Table A3. Educational choice, logit regression

\begin{tabular}{|c|c|c|c|c|c|c|c|c|}
\hline VARIABLES & (1) & (2) & (3) & (4) & $(5)$ & (7) & (8) & (9) \\
\hline Timing & $\begin{array}{c}0.130 \\
(0.809)\end{array}$ & $\begin{array}{c}0.122 \\
(0.797)\end{array}$ & $\begin{array}{c}0.129 \\
(0.803)\end{array}$ & & & & & \\
\hline Risk & & $\begin{array}{c}-0.015 \\
(-0.155)\end{array}$ & $\begin{array}{c}-0.010 \\
(- \\
0.0992)\end{array}$ & & $\begin{array}{c}-0.030 \\
(-0.299)\end{array}$ & $\begin{array}{c}-0.028 \\
(-0.276)\end{array}$ & $\begin{array}{c}-0.001 \\
(- \\
0.0142)\end{array}$ & $\begin{array}{c}-0.002 \\
(- \\
0.0226)\end{array}$ \\
\hline Patience & & $\begin{array}{c}0.073 * * \\
(2.522)\end{array}$ & $\begin{array}{c}0.070 * * \\
(2.406)\end{array}$ & & $\begin{array}{c}0.068 * * \\
(2.345)\end{array}$ & $\begin{array}{c}0.066^{* *} \\
(2.261)\end{array}$ & $\begin{array}{c}0.071 * * \\
(2.438)\end{array}$ & $\begin{array}{r}0.069 * * \\
(2.355)\end{array}$ \\
\hline Priorities & & $\begin{array}{c}0.474 \\
(1.063)\end{array}$ & $\begin{array}{c}0.518 \\
(1.188)\end{array}$ & & $\begin{array}{c}0.461 \\
(1.056)\end{array}$ & $\begin{array}{c}0.480 \\
(1.141)\end{array}$ & $\begin{array}{c}0.497 \\
(1.059)\end{array}$ & $\begin{array}{c}0.502 \\
(1.115)\end{array}$ \\
\hline Age & & & $\begin{array}{c}-0.257 \\
(-0.539)\end{array}$ & & & $\begin{array}{c}-0.145 \\
(-0.310)\end{array}$ & & $\begin{array}{c}-0.087 \\
(-0.183)\end{array}$ \\
\hline Educ father & & & $\begin{array}{c}-0.028 \\
(-0.218)\end{array}$ & & & $\begin{array}{c}-0.022 \\
(-0.173)\end{array}$ & & $\begin{array}{c}-0.026 \\
(-0.199)\end{array}$ \\
\hline Educ mother & & & $\begin{array}{c}0.131 \\
(0.946)\end{array}$ & & & $\begin{array}{c}0.136 \\
(0.972)\end{array}$ & & $\begin{array}{c}0.123 \\
(0.855)\end{array}$ \\
\hline \#siblings & & & 0.074 & & & 0.074 & & 0.082 \\
\hline
\end{tabular}


$(0.471)$

$\begin{array}{ccc} & & (0.470) \\ 0.345 & 0.353 & 0.332 \\ (1.277) & (1.264) & (1.149)\end{array}$

(0.493)

Puberty 5

Breast

$0.385 * * \quad 0.399 * * \quad 0.385 * *$

(2.229) (2.223) (2.096)

Observations $\quad 216 \quad 216$

216

215

215

215

215

$215 \quad 215$

Robust t-statistics in parentheses

$* * * \mathrm{p}<0.01, * * \mathrm{p}<0.05, * \mathrm{p}<0.1$

Table A4. Educational aspiration controlling for grades, OLS regression

\begin{tabular}{|c|c|c|c|c|c|c|c|c|c|}
\hline VARIABLES & (1) & (2) & (3) & (4) & (5) & (6) & (7) & (8) & (9) \\
\hline Timing & $\begin{array}{l}0.090 * \\
(1.867)\end{array}$ & $\begin{array}{l}0.086^{*} \\
(1.776)\end{array}$ & $\begin{array}{c}0.076 \\
(1.540)\end{array}$ & & & & & & \\
\hline Grades & $\begin{array}{c}0.005 * * * \\
(4.429)\end{array}$ & $\begin{array}{c}0.005 * * * \\
(4.048)\end{array}$ & $\begin{array}{c}0.005 * * * \\
(3.707)\end{array}$ & $\begin{array}{c}0.006 * * * \\
(4.782)\end{array}$ & $\begin{array}{c}0.006 * * * \\
(4.291)\end{array}$ & $\begin{array}{c}0.005 * * * \\
(3.878)\end{array}$ & $\begin{array}{c}0.006 * * * \\
(4.860)\end{array}$ & $\begin{array}{c}0.006 * * * \\
(4.481)\end{array}$ & $\begin{array}{c}0.005^{* * *} * \\
(4.052)\end{array}$ \\
\hline Risk & & $\begin{array}{c}-0.076 * * \\
(-2.119)\end{array}$ & $\begin{array}{c}-0.077 * * \\
(-2.169)\end{array}$ & & $\begin{array}{c}-0.072 * * \\
(-2.019)\end{array}$ & $\begin{array}{c}-0.072 * * \\
(-2.037)\end{array}$ & & $\begin{array}{c}-0.078 * * \\
(-2.163)\end{array}$ & $\begin{array}{c}-0.078 * * \\
(-2.160)\end{array}$ \\
\hline Patience & & $\begin{array}{c}0.000 \\
(0.0389)\end{array}$ & $\begin{array}{c}0.000 \\
(0.0010)\end{array}$ & & $\begin{array}{c}0.004 \\
(0.481)\end{array}$ & $\begin{array}{c}0.004 \\
(0.467)\end{array}$ & & $\begin{array}{c}0.004 \\
(0.422)\end{array}$ & $\begin{array}{c}0.004 \\
(0.408)\end{array}$ \\
\hline Priorities & & $\begin{array}{c}-0.198 * * \\
(-2.183)\end{array}$ & $\begin{array}{c}-0.164 * * \\
(-2.028)\end{array}$ & & $\begin{array}{c}-0.214 * * \\
(-2.535)\end{array}$ & $\begin{array}{c}-0.181 * * \\
(-2.405)\end{array}$ & & $\begin{array}{c}-0.221 * * * \\
(-2.685)\end{array}$ & $\begin{array}{c}-0.187 * * \\
(-2.559)\end{array}$ \\
\hline Age & & & $\begin{array}{c}0.105 \\
(0.716)\end{array}$ & & & $\begin{array}{c}0.168 \\
(1.168)\end{array}$ & & & $\begin{array}{c}0.166 \\
(1.175)\end{array}$ \\
\hline Educ father & & & $\begin{array}{c}0.051 \\
(1.116)\end{array}$ & & & $\begin{array}{c}0.047 \\
(1.029)\end{array}$ & & & $\begin{array}{c}0.047 \\
(1.022)\end{array}$ \\
\hline Educ mother & & & $\begin{array}{l}0.093^{*} \\
(1.659)\end{array}$ & & & $\begin{array}{l}0.095^{*} \\
(1.689)\end{array}$ & & & $\begin{array}{l}0.095^{*} \\
(1.681)\end{array}$ \\
\hline \# siblings & & & $\begin{array}{c}-0.042 \\
(-0.824)\end{array}$ & & & $\begin{array}{c}-0.033 \\
(-0.646)\end{array}$ & & & $\begin{array}{c}-0.032 \\
(-0.644)\end{array}$ \\
\hline Puberty 5 & & & & $\begin{array}{c}-0.080 \\
(-1.174)\end{array}$ & $\begin{array}{c}-0.088 \\
(-1.317)\end{array}$ & $\begin{array}{c}-0.081 \\
(-1.254)\end{array}$ & & & \\
\hline Breast & & & & & & & $\begin{array}{c}-0.053 \\
(-0.950)\end{array}$ & $\begin{array}{c}-0.076 \\
(-1.337)\end{array}$ & $\begin{array}{c}-0.070 \\
(-1.269)\end{array}$ \\
\hline Observations & 208 & 208 & 208 & 212 & 212 & 212 & 212 & 212 & 212 \\
\hline R-squared & 0.135 & 0.167 & 0.214 & 0.123 & 0.155 & 0.206 & 0.123 & 0.158 & 0.209 \\
\hline
\end{tabular}

Robust t-statistics in parentheses

$* * * \mathrm{p}<0.01, * * \mathrm{p}<0.05, * \mathrm{p}<0.1$

Table A5. Educational choice controlling for grades, OLS regression

\begin{tabular}{|c|c|c|c|c|c|c|c|c|c|}
\hline VARIABLES & (1) & (2) & (3) & (4) & (5) & (6) & (7) & (8) & (9) \\
\hline Timing & $\begin{array}{c}0.005 \\
(0.194)\end{array}$ & $\begin{array}{c}0.005 \\
(0.198)\end{array}$ & $\begin{array}{c}0.003 \\
(0.132)\end{array}$ & & & & & & \\
\hline Grades & $\begin{array}{c}0.003 * * * \\
(5.237)\end{array}$ & $\begin{array}{c}0.003 * * * \\
(4.686)\end{array}$ & $\begin{array}{c}0.003 * * * \\
(4.579)\end{array}$ & $\begin{array}{c}0.003 * * * \\
(5.262)\end{array}$ & $\begin{array}{c}0.003 * * * \\
(4.711)\end{array}$ & $\begin{array}{c}0.003 * * * \\
(4.594)\end{array}$ & $\begin{array}{c}0.003 * * * \\
(5.108)\end{array}$ & $\begin{array}{c}0.003 * * * \\
(4.581)\end{array}$ & $\begin{array}{c}0.003 * * * \\
(4.477)\end{array}$ \\
\hline Risk & & $\begin{array}{c}0.006 \\
(0.357)\end{array}$ & $\begin{array}{c}0.006 \\
(0.369)\end{array}$ & & $\begin{array}{c}0.006 \\
(0.349)\end{array}$ & $\begin{array}{c}0.006 \\
(0.358)\end{array}$ & & $\begin{array}{c}0.008 \\
(0.477)\end{array}$ & $\begin{array}{c}0.008 \\
(0.477)\end{array}$ \\
\hline Patience & & $\begin{array}{c}0.006 \\
(1.143)\end{array}$ & $\begin{array}{c}0.005 \\
(1.046)\end{array}$ & & $\begin{array}{c}0.005 \\
(1.106)\end{array}$ & $\begin{array}{c}0.005 \\
(1.021)\end{array}$ & & $\begin{array}{c}0.006 \\
(1.164)\end{array}$ & $\begin{array}{c}0.005 \\
(1.079)\end{array}$ \\
\hline Priorities & & $\begin{array}{c}0.020 \\
(0.690)\end{array}$ & $\begin{array}{c}0.027 \\
(0.902)\end{array}$ & & $\begin{array}{c}0.021 \\
(0.740)\end{array}$ & $\begin{array}{c}0.027 \\
(0.926)\end{array}$ & & $\begin{array}{c}0.024 \\
(0.844)\end{array}$ & $\begin{array}{c}0.030 \\
(1.019)\end{array}$ \\
\hline Age & & & -0.010 & & & 0.000 & & & 0.001 \\
\hline
\end{tabular}


Educ father

Educ mother

\# siblings

Puberty 5

Breast
$(-0.144)$

$-0.001$

$(-0.0378)$

0.022

(0.871)

0.011

(0.464)

$\begin{array}{ccc} & & (0.00419) \\ & & -0.001 \\ & & (-0.0630) \\ & & 0.021 \\ & & (0.848) \\ & & 0.011 \\ & & (0.478) \\ 0.036 & 0.034 & 0.032 \\ (0.853) & (0.795) & (0.727)\end{array}$

$\begin{array}{lll}0.031 & 0.033 & 0.031\end{array}$

(1.182) (1.246) (1.167)
(0.0227)

$-0.001$

$(-0.0555)$

0.021

(0.823)

0.010

(0.447)

234

234

234

234

234

234

234

234

R-squared

0.143

0.150

0.155

0.145

0.152

0.157

$0.147 \quad 0.155$

0.159 $* * * \mathrm{p}<0.01, * * \mathrm{p}<0.05, * \mathrm{p}<0.1$ 